\title{
STUDI PENERAPAN ESTRUS SYNCHRONIZATION DAN TEKNOLOGI IB JENIS BOER TERHADAP RESPON BIRAHI DAN KEBUNTINGAN KAMBING LOKAL PADA KELOMPOK PETANI PETERNAK “TELAGA TERNAK MANDIRI” DI KABUPATEN LAMONGAN
}

\author{
Edy Susanto* dan Mufid Dahlan*
}

\author{
* Program Studi Peternakan Fakultas Peternakan Universitas Islam Lamongan
}

Jl.Veteran No.53.A Lamongan

\begin{abstract}
Lamongan merupakan wilayah kering yang banyak terdapat populasi kambing lokal (kacang cross) dan diusahakan oleh peternak rakyat secara tradisional. Tujuan dari penelitian ini adalah untuk mengetahui hasil penerapan Estrus Synchronization dan teknologi IB jenis Boer terhadap persentase birahi dan kebuntingan kambing lokal pada kelompok petani peternak "Telaga Ternak Mandiri" di Kabupaten Lamongan. Penelitian dilaksanakan di Desa Tlogoagung Kecamatan Kembangbahu Kabupaten Lamongan mulai tanggal 2 april - 30 juli 2016. Metode penelitian yang digunakan adalah metode Studi analitis yaitu seperti pada desain percobaan (Nazir, 2005). Sampel yang digunakan sebanyak 20 kambing lokal. Semen beku yang digunakan breed australian boer galur Banjo dan Klien Diamond yang diperoleh dari Laboratorium Lapang "Sumber Sekar" Fakultas Peternakan Universitas Brawijaya. Hasil penelitian menunjukkan bahwa penerapan Estrus Synchronization PGF2 $\alpha$ pada kambing lokal di kabupaten Lamongan menghasilkan respon birahi tertinggi sebesar $80 \%$ dicapai pada dosis $1,5 \mathrm{ml} /$ ekor. Rerata angka kebuntingan hasil teknologi IB jenis boer terhadap kambing lokal di kabupaten lamongan adalah sebesar $75 \%$.
\end{abstract}

Kata Kunci : IB, Estrus Synchronization, Boer, Kambing Lokal, Lamongan

\section{PENDAHULUAN}

Kambing merupakan salah satu ternak ruminansia kecil yang sangat berperan dalam penyediaan kebutuhan protein hewani masyarakat Indonesia. Produktivitas biologis kambing 8-28\% lebih tinggi dibandingkan sapi dengan jumlah anak per kelahiran (litter size) bervariasi 1 sampai dengan 3 ekor (Devendra, 1975 ; Wijoseno dkk., 2009).

Usaha ternak kambing banyak dilakukan oleh peternakan skala rakyat dengan kepemilikan 3-10 ekor. Provinsi Jawa Timur merupakan salah satu sentra populasi ternak kambing di Indonesia. Data Statistik PKH (2013) menyebutkan bahwa populasi ternak kambing di Jawa Timur terus meningkat sejak tahun 2009 ( 2.779 .542 ekor), 2010 (2.822.912 ekor), 2011 (2.830.915 ekor), 2012 (2.879.369 ekor) dan 2013 (2.951.463). Salah satu daerah pengembangan ternak kambing adalah di Kabupaten Lamongan dengan populasi menurut data Dinas PKH Kabupaten Lamongan adalah sejumlah 46.000 ekor di tahun 2014.

Desa Tlogoagung Kecamatan Kembangbahu Kabupaten Lamongan merupakan salah satu desa yang masyarakatnya banyak bermata pencaharian sebagai petani dan peternak. Kepemilikan ternak kambing di desa Tlogoagung rata-rata adalah 1-3 ekor/KK dengan status milik sendiri maupun memelihara milik orang lain (paruhan). Jenis kambing yang dipelihara terdiri dari kambing lokal "kacang" dan peranakannnya. kegiatan utama adalah usaha pembibitan. Usaha ini dirasa sangat membantu dalam meningkatkan pendapatan keluarga tani. Pola padi-palawija-ternak sudah sejak lama dilakukan oleh masyarakat setempat. Keuntungan saat panen tanaman pangan maupun palawija biasanya dibelikan ternak kambing. Pada saatnya musim tanam tiba ternak tersebut dijual kembali. Kondisi ternak tersebut biasanya sudah mendapatkan keuntungan. Kelompok Tani "Rukun Tani II" dan Kelompok Ternak "Telaga Ternak Mandiri" merupakan kelembagaan yang berfungsi sebagai organisasi petani dan peternak di desa Tlogoagung. Secara umum kondisi usaha budidaya ternak kambing di desa Tlogoagung masih dikelola secara tradisional. Banyak permasalahan yang ada diantaranya : Kompetensi produksi ternak kambing peternak yang masih kurang, sistem perkandangan yang belum layak standar, belum menggunakan bibit unggul, dan manajemen reproduksi yang masih tradisional. Permasalahan tersebut menjadikan peternak cenderung merugi karena produktivitas ternak yang tidak bisa tinggi.

Perkembangan populasi ternak kambing di kelompok "Telaga Ternak Mandiri" sejak tahun 2012 hingga kini tercatat dari 60 ekor menjadi 88 ekor atau meningkat hanya sekitar 1,4 kali. Berdasarkan litter size ternak kambing idealnya dalam jangka waktu 2 tahun tersebut telah berkembang $2-3$ kali lipat (Parwati, 2003). Faktor yang menyebabkan kurang berkembangnya ternak kambing di kelompok ini adalah pelaksanaan manajemen reproduksi yang masih tradisional. 
Sejauh ini sudah ada peternak yang membeli 1-2 ekor jenis kambing unggul seperti Jenis Peranakan Etawa (PE). Kambing tersebut banyak dibeli dari luar wilayah kabupaten Lamongan dengan tujuan hanya dibesarkan. Belum ada pembibitan khusus yang dilakukan peternak sehingga kebutuhan bibit unggul masih sangat bergantung dari daerah lain. Kambing jenis PE yang secara alami merupakan salah satu jenis kambing yang di budidayakan dengan tujuan utama Perah (Produksi susu) selama ini kurang bisa optimal di Kabupaten Lamongan. Hal ini disebabkan Lamongan merupakan daerah yang secara klimatologis beriklim kering sehingga produksi susu kambing PE tidak bisa maksimal. Perlu adanya introduksi jenis kambing unggul tipe pedaging yang lebih optimal dikembangkan di Kabupaten Lamongan diantaranya Kambing Boer.

\section{METODE PENELITIAN}

Metode penelitian yang digunakan adalah metode Studi analitis yaitu seperti pada desain percobaan (Nazir, 2005). Sampel yang digunakan sebanyak 20 kambing lokal yang ada di peternak rakyat Kelompok Petani Peternak "Telaga Ternak mandiri" Desa Tlogoagung Kecamatan Kembangbahu kabupaten Lamongan secara acak. Semen beku yang digunakan breed australian boer galur Banjo dan Klien Diamond yang diperoleh dari Laboratorium Lapang "Sumber Sekar" Fakultas Peternakan Universitas Brawijaya

\section{Prosedur Penelitian}

\section{Teknik Sinkronisasi}

Prosedur Estrus Synchronization dilakukan sesuai prosedur Caprifarmindo Labs. (2015) yaitu :

1. membawa kambing betina di tempat yang datar dan teduh (bila memungkinkan bisa dilakukan di dalam kandang).

2.Salah seorang operator mengempit leher kambing dengan duo bush kaki dan kepala menghadap ke ekor (belakang). Bila kambing memberontak tarik kedua telinganya.

3.Seorang operator yang lain memberikan perlakuan Injeksi Hormon PGF2 $\alpha$ (Merk dagang : Capriglandin Inj.) dengan cara : 2 kali injeksi $\mathrm{PGF}_{2}$ a (pengulangan hr ke -10 sampai dengan -12 dari saat injek I,. Injeksi dilakukan secara Intra muscular dengan dosis $1,5 \mathrm{ml} / \mathrm{ekor}$.

4.Perkawinan (IB) dilakukan saat estrus atau 72-96 jam stlh injeksi ke -2. Atau bila birahi mulai malam/sore hari, dikawinkan pagi atau siang hari. Bila mulai birahi pagi, dikawinkan siang atau sore hari.

\section{Teknik Inseminasi Buatan}

\section{Cara Inseminasi Buatan dilakukan sesuai dengan prosedur Kartasudjana (2001) yaitu sebagai berikut :}

1.Mengambil straw dari dalam termos atau container dengan hati-hati;

2.Pegang pada ujung kemasan, baca label yang tertera pada straw secara singkat;

3. Lakukan thawing sekitar 5 detik;

4. Ambil dan keringkan dengan usapan tisu;

5.Tempatkan straw pada ujung Insemination gun, gunting ujung kemasan straw; Pasang plastik sit pada Insemination gun dan fiksasi agar posisi straw baik; Bawa Insemination gun yang telah siap dan speculum ke kandang ternak betina;

6. Dengan pertolongan perawat ternak, angkat kedua kaki belakang kambing/domba sehingga badannya membentuk sudut $40-45$ derajat terhadap lantai kandang;

7.Buka vagina Kambing dengan menggunakan speculum yang sudah diberi vaselin, lihat posisi lubang cervix, incarlah; masukkan Insemination gun melalui lorong speculum menuju ke lubang cervix, dorong hingga ke posisi empat atau batas cervix tertahan suatu tekanan, ujung gun masuk sekitar $1 \mathrm{~cm}$;

8. Semprotkan semen pada bagian tersebut, lalu tarik Insemination gun perlahan-lahan;

9. Tahan posisi Kambing dengan sudut 45 derajat, selama 5 menit;

10. Lepas kedua kaki kambing sehingga dapat berdiri kembali di kandang.

\section{Penilaian Respon Birahi}


Pada penelitian ini data yang diambil adalah jumlah ternak yang menunjukkan ciri-ciri birahi. Respon birahi (RB) dihitung dengan cara membandingkan jumlah ternak yang birahi dengan seluruh jumlah ternak yang diperlakukan sinkronisasi dikalikan seratus persen.

\section{Penilaian Angka Kebuntingan Induk}

Penilaian angka kebuntingan induk didasarkan pada perbandingan jumlah induk betina bunting setelah inseminasi yang ditentukan berdasarkan tidak timbul kembali birahi kebuntingan dalam waktu 15-17 hari setelah inseminasi. Penilaian angka kebuntingan dilakukan dengan menggunakan rumus Conseption Rate sebagai berikut:

$$
\begin{aligned}
& \sum \text { betina bunting IB } \\
& \sum \text { betina yang di IB }
\end{aligned}
$$

\section{ANALISIS DATA}

Data yang dikumpulkan dalam penelitian ini merupakan data primer. Dikumpulkan dengan pengamatan langsung di lapangan dan wawancara langsung dengan responden, menggunakan kuesioner yang telah dipersiapkan sebelumnya. Data dianalisis secara deskriptif

\section{HASIL DAN PEMBAHASAN}

\section{Kualitas Semen Beku}

Sebelum dilakukan inseminasi buatan, semen beku yang akan digunakan terlebih dahulu diuji kualitasnya untuk memastikan kelayakan penggunaannya. Hasil pengujian tersebut dapat dilihat pada Tabel 1.

Tabel 1. Kualitas semen beku pejantan boer

\begin{tabular}{lllcccc}
\hline No & Breed & Galur & $\begin{array}{l}\text { Jumlah } \\
\text { straw (ds) }\end{array}$ & Warna/kode & \multicolumn{2}{c}{ Kualitas } \\
\cline { 6 - 6 } & & & & Motilitas & Konsentrasi \\
\hline 1 & Australian Boer & Banjo & 20 & Ping / 33 & $>85 \%$ & +++ \\
2 & Australian Boer & $\begin{array}{l}\text { Klien } \\
\text { Diamond }\end{array}$ & 20 & Orange / 171 & $>85 \%$ & +++ \\
& & & & & \\
\hline
\end{tabular}

Berdasarkan tabel 1 diketahui bahwa kualitas semen beku boer cukup baik dengan rerata motolitas $>85 \%$ dan Konsentrasi +++ . Hal ini menunjukkan straw tersebut layak untuk digunakan. Sariadi dkk. (2014) menyebutkan bahwa kualitas semen beku yang akan digunakan dalam inseminasi buatan harus motil lebih dari $80 \%$ dan pergerakannya sangat cepat (+++). Eskayanti (2013) menambahkan bahwa persentase motilitas spermatozoa, konsentrasi, dan dan abnormalitas dapat mempengaruhi angka konsepsi.

\section{Respon Birahi}

Sinkronisasi birahi (estrus synchronization) dilakukan dengan dua dosis hormon PGF2 $\alpha$ yang berbeda, hasilnya ditunjukkan pada tabel 2 .

Tabel 2. Respon Birahi kambing lokal

\begin{tabular}{ccc}
\hline No & Perlakuan Dosis PGF2 $\alpha(\mathrm{ml})$ intramuskular & Respon (\%) 48-66 jam \\
\hline 1 & 1,0 & 65,0 \\
\hline
\end{tabular}




$\begin{array}{lll}2 & 1,5 & 80,0\end{array}$

Berdasarkan tabel 2 diketahui bahwa terjadi perbedaan yang cukup besarrespon birahi antara kambing lokal yang diinjeksi intramuskular hormon PGF2 $\alpha$ pada dosis $1,0 \mathrm{ml}$ dan 1,5 ml. Semakin besar dosis yang diberikan maka respon birahi semakin tinggi. Hasil percobaan sinkronisasi juga didapat data dari 20 ekor kambing lokal yang diinjeksi dengan hormon, 14 ekor (70\%) birahi, sedangkan 6 ekor (30\%) lainnya tidak birah. Hal ini seiring dengan pendapat Dogan et.al. (2005) bahwa sinkronisasi akan berhasil jika calon betina sudah diketahui mempunyai corpus luteum di dalam saluran reproduksinya. Kambing yang tidak birahi pada sinkronisasi pertama dapat di injeksi lagi pada selang waktu 10 hari berikutnya. Pada 6 ekor kambing yang disinkronisasi tahap kedua selanjutnya langsung di IB kesesokan harinya.

\section{Angka Kebuntingan}

Hasil penerapan teknologi inseminasi buatan hasil sinkronisasi pada kambing lokal dengan straw kambing boer ditunjukkan pada tabel 3.

Tabel 3. Angka kebuntingan hasil teknologi IB kambing boer

\begin{tabular}{ccccc}
\hline No & Akseptor & Jumlah (ekor) & \multicolumn{2}{c}{ Angka Kebuntingan } \\
\cline { 3 - 5 } & & Jumlah (ekor) & $\begin{array}{c}\text { Prosentase } \\
(\%)\end{array}$ \\
\hline 1 & Kambing lokal hasil sinkronisai I & 14 & 10 & 71,5 \\
2 & Kambing lokal hasil sinkronisai II & 6 & 5 & 83,0 \\
& Jumlah & 20 & 15 & 75,0 \\
\hline
\end{tabular}


Berdasarkan table 3 diketahui bahwa angka kebuntingan kambing lokal hasil teknologi sinkronisasi dan IB jenis boer sebesar 75\%. Hal ini seiring dengan penelitian Hamdan dkk. (2012) bahwa angka kebuntingan kawin buatan (IB) tidak lebih tinggi dari kawin alami. Dari 14 kambing betina yang birahi hasil sinkronisasi pertama didapat angka kebuntingan yang agak rendah sebesar $65 \%$ lebih kecil dibanding angka kebuntingan hasil sinkronisasi kedua sebesar 83,0\%. Hasil ini seiring dengan hasil penelitianpenelitian terdahulu yang menjelaskan bahwa sinkronisasi kedua (dengan jarak 10 hari) akan menghasilkan angka kebuntingan yang lebih tinggi karena peluang terbentuknya corpus luteum lebih tinggi (Fitra dan Doloksaribu, 2008).

\section{KESIMPULAN}

Berdasarkan hasil penelitian disimpulkan bahwa penerapan Estrus Synchronization PGF2 $\alpha$ pada kambing lokal di kabupaten Lamongan menghasilkan respon birahi tertinggi sebesar $80 \%$ dicapai pada dosis $1,5 \mathrm{ml} /$ ekor. Rerata angka kebuntingan hasil teknologi IB jenis boer terhadap kambing lokal di kabupaten lamongan adalah sebesar $75 \%$.

\section{SARAN}

Diperlukan penelitian lebih lanjut terhadap performance hasil Teknologi estrus synchronization dan teknologi IB jenis boer pada kambing lokal di kabupaten Lamongan.

\section{REFERENSI}

Caprifarmindo Labs., 2015. Capriglandin Inj. Hormon PGF2a Injeksi. PT. Caprifarmindo Labs. Bandung.

Disnak Jatim, 2012. Data Ternak Kambing Jalin Kesra Propinsi Jawa Timur. Dinas Peternakan Propinsi Jawa Timur. Surabaya.

Dogan, Nur G., Gumay, 2005. Estrus Synchronization during The Naural Breeding Season inanatolian block does. Vet. Med.-Czech 50 (1) : 33-38

Eskayanti, 2013. Pengaruh Pemisahan Spermatozoa $X$ dan $Y$ menggunakan metode Swim Up terhadap kambing PE. Skripsi FKH. UNSYAH. Banda Aceh.

Fitra, A.P., dan Doloksaribu M., 2008. Penerapan Sinkronisasi Birahi kambing Boerka dengan Lokal di Areal Perkebunan Berbasis Tanaman Jeruk Lahan Kering. Seminar Nasional Teknologi Peternakan dan Veteriner.

Hamdan, Nurcahya D., Siregar, Panjaitan dan Husnurrizal. Kinerja Reproduksi Kambing Lokal yang diinduksi Superovulasi dengan Antessum Inhibin. Jurnal Kedokteran Hewan. Vol.6 No.1

Kartasudjana R., 2001. Teknik Inseminasi Buatan pada Ternak. Modul Program Pengembangan Keahlian Budidaya Ternak. Jakarta.

Parwati, I. A. P., 2003. Pendapatan dan Faktor-Faktor Yang Mempengaruhi Produksi Usaha Ternak Kambing. Balai Pengkajian Teknologi Pertanian. Bali

Sariadi, Saiful dan Akmal M., 2014. Rasio Jenis Kelahiran Anak PE hasil IB menggunakan Spermatozoa Swim Up. Agritek Vol 14 No.1

Wijoseno, S.R., L.G.S. Astiti, T. Panjaitan, A. Muzani dan N. Agustini, 2009. Beternak Kambing Intensif. Balai Pengkajian Teknologi Pertanian. Departemen Pertanian. Jakarta. 